Randomized Trial

\title{
Comparative Outcomes of a 2-Year Follow-Up of Cervical Medial Branch Blocks in Management of Chronic Neck Pain: A Randomized, Double-Blind Controlled Trial
}

Laxmaiah Manchikanti, MD¹, Vijay Singh, MD², Frank J.E. Falco, MD³ , Kimberly A. Cash, RT ${ }^{1}$, and Bert Fellows, $\mathrm{MA}^{1}$

From: ${ }^{1}$ Pain Management Center of Paducah, Paducah, Kentucky; 2Pain Diagnostics Associates, Niagara, WI; and ${ }^{3}$ Mid Atlantic Spine \& Pain Specialists of Newark, Newark, DE.

Dr. Manchikanti is Medical Director of the Pain Management Center of Paducah, Paducah, KY, and Associate Clinical Professor of Anesthesiology and Perioperative Medicine, University of Louisville, Louisville, KY.

Dr. Singh is Medical Director, Pain Diagnostics Associates, Niagara, WI.

Dr. Falco is Medical Director of the Mid Atlantic Spine \& Pain

Specialists of Newark, DE;

Clinical Assistant Professor and Director, Pain Medicine

Fellowship, Temple University Medical School, Philadelphia, PA.

Kimberly A. Cash is a Research Coordinator at the Pain Management Center of Paducah, Paducah, KY.

Bert Fellows, MA, Managing Editor of Pain Physician journal and Director Emeritus of Psychological Services for Pain Management Center of Paducah, Paducah, KY.

Address correspondence: Laxmaiah Manchikanti, MD 2831 Lone Oak Road Paducah, Kentucky 42003 E-mail: drlm@thepainmd.com

Disclaimer: There was no external funding in the preparation of this manuscript. Conflict of interest: None.

Manuscript received: $07 / 12 / 2010$

Accepted for publication: 08/27/2010

Free full manuscript: www.painphysicianjournal.com
Background: Cervical therapeutic intraarticular facet joint injections, therapeutic medial branch blocks, and radiofrequency neurotomy have been applied in managing chronic neck pain of cervical facet joint origin. However, the effectiveness of these modalities continues to be debated.

The purpose of this study was to determine the clinical effectiveness of therapeutic cervical medial branch blocks with or without steroids.

Study Design: A randomized, double-blind, controlled trial.

Setting: An interventional pain management practice, a specialty referral center, a private practice setting in the United States.

Objective: To evaluate the clinical outcomes of therapeutic cervical medial branch blocks with local anesthetic with or without steroids in managing chronic neck pain of facet joint origin.

Methods: A total of 120 patients meeting inclusion criteria were included. All of the patients met the diagnostic criteria of cervical facet joint pain by means of comparative, controlled diagnostic blocks, with at least $80 \%$ relief. Group I consisted of cervical medial branch blocks with bupivacaine only and Group II consisted of cervical medial branch blocks with bupivacaine and steroid.

Therapeutic cervical medial branch blocks with local anesthetic with or without steroids were administered. Main outcome measures included numeric pain scores, Neck Disability Index (NDI), opioid intake, and work status evaluated at baseline, 6, 12, 18, and 24 months. The one-year results of outcomes were published in 2008. This manuscript describes the 2-year results.

Significant improvement was defined as at least 50\% improvement in pain relief and/or functional status improvement.

Outcomes Assessment: Patient outcomes were measured at baseline, 3, 6, 12, 18, and 24 months post-treatment with the Numeric Rating Scale (NRS), the Neck Disability Index (NDI), employment status, and opioid intake. Decrease of $\geq 50 \%$ of NRS scores and Oswestry scores were considered significant.

Results: Eighty-five percent of patients in Group I and 93\% of patients in Group II showed significant pain relief ( $\geq 50 \%$ ) at 2 years. The average number of treatments for 2 years was 5.7. The duration of average pain relief with each procedure was 17-19 weeks on average in both groups. Significant improvement of pain and function was demonstrated for 83 to 89 weeks over a period of 2 years.

Limitations: The study limitations include the lack of a placebo group.

Conclusions: In this study, therapeutic cervical medial branch blocks instituted after the diagnosis, with controlled comparative local anesthetic blocks with $80 \%$ concordant pain relief, repeated approximately 6 times over a period of 2 years, provided significant improvement over a period of 2 years.

Key words: Chronic neck pain, cervical facet or zygapophysial joint pain, facet joint nerve or medial branch blocks, comparative controlled local anesthetic blocks, therapeutic cervical facet joint nerve blocks

Clinical Trial: NCT00332722

Pain Physician 2010; 13:437-450 
hronic neck pain is a common phenomenon, with evidence indicating that between $50 \%$

to $75 \%$ of people who experience neck pain initially, also report neck pain one to 5 years later (1-8). The annual prevalence estimates of neck pain average between $30 \%$ and $50 \%$ (8-18). This pain is associated with significant economic, societal, and health effects $(1,8,18-22)$..

Cervical intervertebral discs, cervical facet joints, atlanto-axial and atlanto-occipital joints, ligaments, fascia, muscles, and nerve root dura have been shown to be capable of transmitting pain in the cervical spine with resulting symptoms of neck pain, upper extremity pain, and headache (23-25). However, very little is known about the causes of neck pain since the epidemiologic studies do not describe either the source or cause of pain. In a study undertaken in order to provide a first approximation of the possible sources and causes of neck pain, Yin and Bogduk (25), in a private practice pain clinic in the United States, provided the approximation of the prevalence of zygapophysial joint pain in $55 \%$, discogenic pain in $16 \%$, and lateral atlanto-axial joint pain in $9 \%$ of the 143 patients with chronic neck pain. However, a large proportion of patients $(36 \%)$ did not pursue investigations, which diluted the crude prevalence of various conditions and a further $17 \%$ deferred completing investigations with only $46 \%$ of the patients completing the investigations (25). Based on controlled diagnostic blocks, utilizing $80 \%$ relief as the criterion standard and the ability to perform previously painful movements, Falco et al (23) showed the prevalence of cervical facet joint pain ranging from $36 \%$ to $54 \%$, with an average prevalence of $49 \%$ with a false-positive rate of $27 \%$ to $63 \%$ (average $49 \%$ ) with a single block (2532). In addition, Rubinstein and van Tulder (33), in a best evidence review of diagnostic procedures for neck and low back pain, concluded that there is strong evidence for the diagnostic accuracy of cervical facet joint blocks in evaluating neck pain. The rationale for cervical facet joint pain has been established based on the innervation being a source of pain in the neck and referred pain in the head and upper extremities, and a preponderance of evidence supporting the existence of cervical facet joint pain and its prevalence utilizing controlled diagnostic blocks (23-36).

Nevertheless, substantial debate surrounds the value and validity of diagnostic cervical facet joint nerve blocks (37-40), with continued general confusion and debate with regards to placebo control for diagnostic and therapeutic trials (41-50). Consequently, the criterion standard is not only limited to biopsy, but also long-term follow-up criteria. The studies in the lumbar spine have shown the value of controlled comparative local anesthetic blocks with $80 \%$ and concordant pain relief and long-term follow-up of 2 years $(51,52)$. The results of these evaluations showed that with $80 \%$ pain relief, the diagnosis was maintained after 2 years of follow-up with therapeutic interventional techniques directed at managing facet joint pain. In addition, the influence of multiple confounding factors has also been evaluated without influence on the diagnostic value of cervical facet joint nerve blocks (23,26-28,35,51-58). Thus, despite debate and differences of opinions, it appears that diagnostic facet joint nerve blocks are the only method of choice in the diagnosis of facet joint pain.

Similar to diagnosis, significant debate surrounds the appropriate management of cervical facet joint pain $(23,33-35)$. The systematic review by Falco et al (23) showed a lack of evidence for cervical therapeutic intraarticular facet joint injections. However, they showed moderate evidence for cervical medial branch blocks and radiofrequency neurotomy, that has also been echoed in other reports $(34,41,42,59,60)$. Thus, medial branch blocks may be utilized as an alternative to radiofrequency neurotomy. Previously, Manchikanti et al published an observational study (61) and a randomized double-blind trial $(45,62)$ illustrating positive results in $85 \%$ or $92 \%$ of patients at one-year follow-up in the randomized trial with medial branch blocks performed with or without steroids.

This report consists of the 2-year results of the randomized, double-blind controlled trial in patients with a confirmed diagnosis of cervical facet joint pain by means of comparative, controlled, local anesthetic blocks based on modified International Association for the Study of Pain (IASP) criteria with $80 \%$ pain relief and the ability to perform previously painful movements $(23,35,63)$. The results of the one-year follow-up were published previously (45).

\section{Methods}

The study protocol was approved by the Institutional Review Board and has been registered with clinical trial registry as NCT0033272. The study was conducted in an interventional pain management practice, a specialty referral center, a private practice setting in the United States, according to CONSORT guidelines $(64,65)$. 


\section{Participants}

All the participants were recruited from consecutive new patients presenting to an interventional pain management practice with neck pain without suspected disc herniation or radiculitis. All the patients who had tested positive with diagnostic facet joint nerve blocks were invited to participate in the study. One hundred twenty patients were assigned to one of the 2 groups constituting either a non-steroid group (Group I) or a steroid group (Group II). Both groups were also divided into 2 categories each with the addition of Sarapin $\bigotimes$ (High Chemical Co., Levittown, PA). Both groups received bupivacaine with or without steroid. However, category $B$ patients also received Sarapin in both groups.

\section{Inclusion and Exclusion Criteria}

Inclusion criteria consisted of those patients with a history of chronic function-limiting neck pain of at least 6 months duration, 18 years of age, those patients who were able to provide voluntary written informed consent, willing to participate in the study as well as follow-up, and those with positive results with controlled diagnostic cervical facet joint nerve blocks with at least $80 \%$ concordant pain relief and the ability to perform previously painful movements.

Exclusion criteria included disc herniation with radicular pain, symptomatic spinal stenosis, surgical interventions of the cervical spine within the last 3 months, uncontrolled major depression or psychiatric disorders, heavy opioid usage (morphine equivalent of $300 \mathrm{mg}$ ), acute or uncontrolled medical illness, chronic severe conditions that could interfere with the interpretations of the outcome assessments, women who were pregnant or lactating, patients unable to be positioned in a prone position, and patients with a history of adverse reactions to local anesthetics, Sarapin, or steroids.

\section{Interventions}

All of the patients were provided with the informed consent and protocol approved by the Institutional Review Board, which described details of the trial including side effects and the mechanisms of withdrawal from the study.

\section{Diagnostic Cervical Medial Branch Blocks}

All patients included in the study underwent controlled comparative local anesthetic blocks, using $0.5 \mathrm{~mL}$ of $1 \%$ lidocaine, followed by $0.5 \mathrm{~mL}$ of $0.25 \%$ bupivacaine on a separate occasion, usually 3 to 4 weeks after the first injection, if the results were positive with the lidocaine block. All the blocks were performed with intermittent fluoroscopic visualization using a 22-gauge, 2-inch spinal needle at each of the indicated medial branches in a sterile operating room. Intravenous access was established and light sedation with midazolam was offered to all patients. A response was considered positive, with $80 \%$ pain relief of at least 2 hours for lidocaine, and 3 hours for bupivacaine, as well as the ability to perform multiple maneuvers which were painful prior to diagnostic facet joint blocks. All other types of responses were considered negative; however, the diagnostic phase was not part of the study.

\section{Therapeutic Cervical Medial Branch Blocks}

In the therapeutic phase, patients were treated with medial branch blocks under fluoroscopy in a sterile ambulatory surgery setting with a 22-gauge 2-inch or longer spinal needle with injection of 0.5 to $1 \mathrm{~mL}$ mixture as assigned by the grouping at each level.

\section{Co-Interventions}

All the patients were provided with the same cointerventions as needed with opioid and non-opioid analgesics, adjuvant analgesics, and previously directed exercise programs prior to enrollment in the study. The adjustments in medical therapy were carried out based on the response to injection therapy and physical and functional needs. However, no specific co-interventions such as physical therapy or occupational therapy were provided.

\section{Additional Interventions}

Patients were followed at 3-month intervals unless otherwise indicated and cervical medial branch blocks were repeated based on the response to the prior interventions with improvement in physical and functional status. The cervical medial branch blocks were repeated only when reported pain levels deteriorated to below $50 \%$, with initial report of significant pain relief of $50 \%$ or more after the previous block. The non-responsive patients receiving other types of treatments after stopping therapeutic cervical facet joint nerve blocks were considered to be withdrawn from the study, and no subsequent data were collected. For patients continued with conservative management, without unblinding, data collection was continued.

\section{Objective}

The objective of this randomized, double-blind, controlled trial is to determine the clinical outcomes of 
therapeutic cervical medial branch blocks with local anesthetic with or without steroids in managing chronic neck pain of facet joint origin.

\section{Outcomes}

Outcomes measured included numeric rating scale (NRS), Neck Disability Index (NDI), work status, and opioid intake in terms of morphine equivalents, assessed at baseline, 3, 6, 12, 18, and 24 months post-treatment.

Significant improvement was defined as at least $50 \%$ pain relief and/or improvement in NDI. NRS is represented as " 0 " with no pain and " 10 " with worst pain imaginable. The NRS has been frequently utilized for pain measurements and its value and validity have been reported.

The NDI has been shown to be valid and reliable in patients with mechanical neck pain measured on a scale of 0 to 50 with " 0 " being no disability and " 50 " being the worst disability (66-69). Further, reported thresholds for the minimum clinically important difference for the NDI ranged from a $10 \%$ to $19 \%$ change, even though recent literature demands higher improvements for outcome measurements $(70,71)$.

Opioid intake was evaluated based on the dosage frequency and schedule of the drug, with conversion to morphine equivalents (72).

Patients unemployed or employed on a part-time basis with limited or no employment due to pain were classified as employable. Patients who chose not to work, were retired, or were homemakers (not working, but not due to pain) were not considered in the employment pool.

\section{Sample Size}

For this evaluation, a sample size of 60 patients for each group was chosen. The sample size was much smaller in previous studies of cervical (73) and lumbar (74) medial branch neurotomies, which included less than 20 patients in each group. The literature evaluating the quality of individual articles has shown a sample size of 50 patients in the smallest group as acceptable (75).

\section{Randomization}

Thirty patients were randomly assigned into each subgroup, with 60 patients in each group from a total of 120 patients.

\section{Sequence Generation}

Randomization was carried out in blocks of 20 patients by computer-generated random allocations sequence.

\section{Allocation Concealment}

Patients were randomized and the drugs were prepared appropriately by the operating room nurse assisting with the procedure. All mixtures consisted of clear solutions. Bupivacaine and Sarapin were mixed in equal volumes, and $0.15 \mathrm{mg}$ of non-particulate betamethasone was added per $\mathrm{mL}$ of solution in the steroid group.

\section{Implementation}

After the patients met the inclusion criteria, one of the 3 nurses assigned as coordinators of the study enrolled the participants and assigned participants to their respective groups. All the patients meeting inclusion criteria were invited to enroll in the study.

\section{Blinding}

The random allocation was not revealed to personnel in the recovery room or to the physician performing the procedure. Study patients were mixed with other patients with no specific indication that patients were participating in the study.

Patients were unblinded if they requested to be unblinded or after completing 24 months of the study. Patients were provided with an opportunity to discontinue or withdraw from the study for lack of pain relief or for any other reason. All the patients with loss of follow-up or premature unblinding were considered to be withdrawn.

All the patients were unblinded at 24 months.

\section{Statistical Methods}

Chi-squared statistic, Fisher's exact test, paired ttest, and one-way analysis of variance were used to analyze the data.

Chi-squared statistic was used to test the differences in proportions. Fisher's exact test was used wherever the expected value was less than 5 . A paired t-test was used to compare the pre- and post-treatment results of average pain scores and the NDI measurements at baseline versus $6,12,18$, and 24 months. The t-test was performed for comparison of mean scores between groups. One-way analysis of variance was used for comparison of means among groups.

Initially, categories with or without Sarapin in each group were analyzed by comparing them to each other. Subsequently, local anesthetic and steroid groups were compared if there were no differences.

\section{Intent-to-Treat-Analysis}

An intent-to-treat-analysis was utilized on all patients utilizing the last follow-up data. Initial data were 
utilized in the patients who dropped out of the study without further follow-up after first treatment. Sensitivity analysis was performed utilizing best case, worst case, and last follow-up scores scenarios.

\section{Results}

\section{Participant Flow}

Figure 1 illustrates the participant flow.

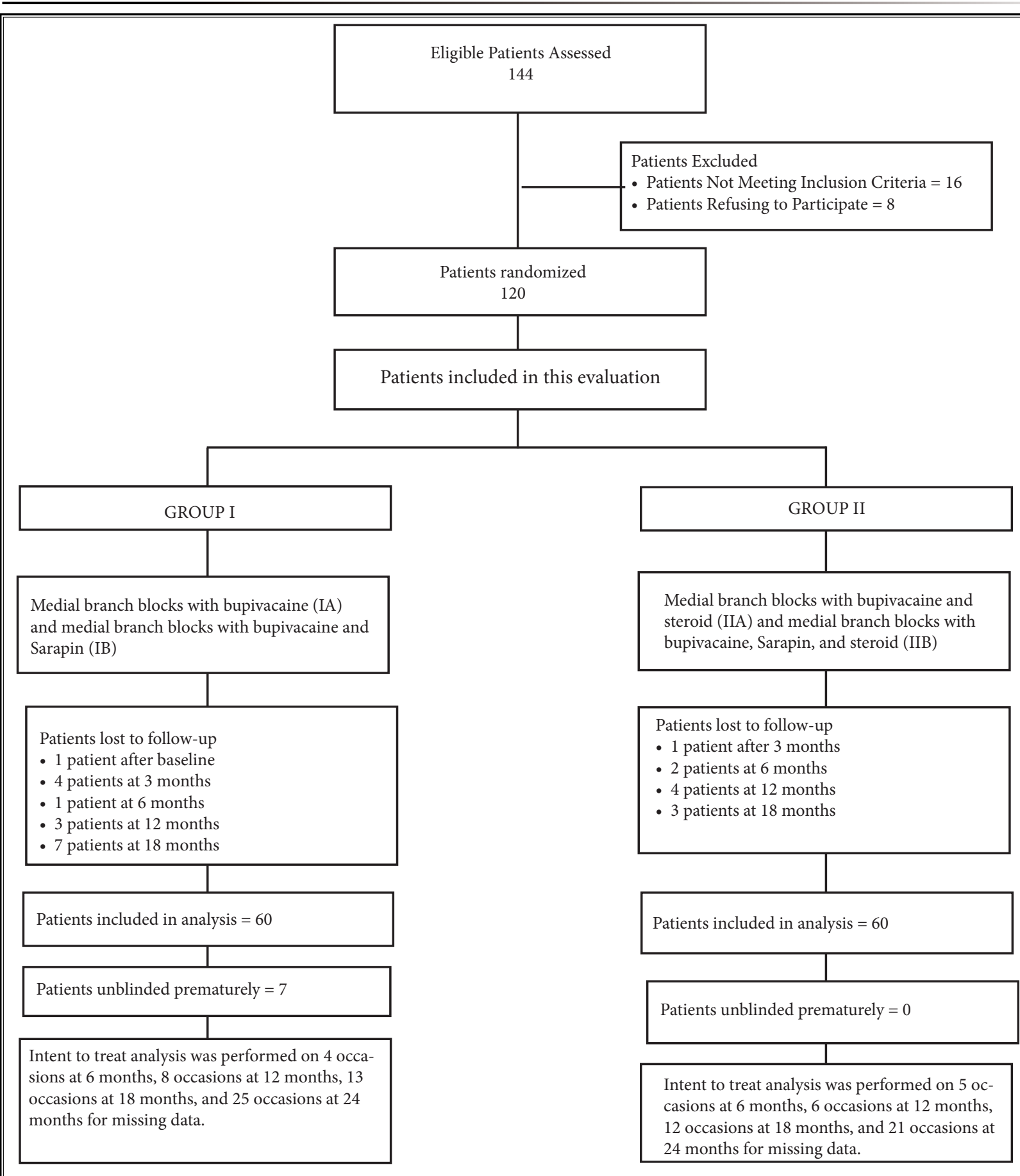

Fig. 1. Schematic presentation of patient flow at 2-year follow-up. 


\section{Recruitment}

The recruitment period lasted from November 2003 to July 2006.

\section{Baseline Data}

Demographic characteristics are illustrated in Table 1. There were no significant differences noted among the groups.

The number of joints involved was as follows: 2 joints were involved in $48 \%$ of the patients, 3 joints were involved in $52 \%$ of the patients, and 4 joints were involved in $2 \%$ of the patients. Bilateral involvement was seen in $73 \%$ of the patients.

\section{Analysis of Data}

\section{Numbers Analyzed}

Data were analyzed for both categories in each group to evaluate the influence of Sarapin. There were no significant differences. Thus, descriptions are provided for 2 groups with local anesthetic with or without steroid.

As illustrated in Figure 1, all 120 patients were utilized in the final analysis after 2 years. Intent-to-treat analysis was performed on Group I on 4 occasions at 6 months, 8 occasions at 12 months, 13 occasions at 18 months, and 25 occasions at 24 months for missing data. Similarly, for Group II intent-to-treat analysis was performed on 5 occasions at 6 months, 6 occasions at 12 months, 12 occasions at 18 months, and 21 occasions at 24 months for missing data. In Groups I and II a maximum of 7 and 4 patients were lost to follow-up. Total analyses points were 300 for each group, with intentto-treat analysis applied in 51 of 300 occasions in Group I (17\%) and 45 of 300 occasions in Group II (15\%).

\section{Missing Data}

A sensitivity analysis with changes in numeric pain scale was performed utilizing last follow-up score, best case scenario, and worst case scenario. There were no significant differences; hence, intention-to-treat analysis with last follow-up visit was utilized.

\section{Outcomes}

\section{Pain Relief}

Numeric pain scale scores are illustrated in Table 2 and Figure 2 . There were significant changes in pain scores from baseline at 6, 12, 18, and 24 months in both groups, with no differences between Groups I and II. The percentage of patients with significant pain relief was $85 \%, 92 \%$, at one-year and $85 \%, 93 \%$, at 2 years in Groups I and II respectively.

Table 3 illustrates therapeutic procedural characteristics with average pain relief over a period of 2 years.

Table 1. Demographic characteristics.

\begin{tabular}{|l|c|c|c|}
\hline \multirow{2}{*}{ Gender } & & $\begin{array}{c}\text { Group I } \\
\text { (bupivacaine without } \\
\text { steroid) } \\
\mathbf{( N = 6 0 )}\end{array}$ & $\begin{array}{c}\text { Group II } \\
\text { (bupivacaine with steroid) } \\
\text { (N = 60) }\end{array}$ \\
\hline \multirow{2}{*}{ Age } & Male & $32 \%(19)$ & $20 \%(12)$ \\
\hline \multirow{2}{*}{ Height (inches) } & Female & $68 \%(41)$ & $80 \%(48)$ \\
\hline \multirow{2}{*}{ Weight (lbs.) } & Mean \pm SD & $46 \pm 13$ & $43 \pm 14$ \\
\hline \multirow{2}{*}{ Duration of pain (months) } & Mean \pm SD & $66 \pm 3.9$ & $65 \pm 3.7$ \\
\hline \multirow{3}{*}{ Mode of onset of pain } & Mean \pm SD & $180 \pm 55$ & $169 \pm 42$ \\
\hline
\end{tabular}

$\mathrm{SD}=$ Standard deviation

$\mathrm{WC}=$ Worker's compensation

MVA $=$ Motor vehicle injury 
Table 2. Pain relief characteristics.

\begin{tabular}{|c|c|c|c|}
\hline \multicolumn{3}{|c|}{ NON-STEROID GROUP } & \multirow{2}{*}{$\begin{array}{c}\text { STEROID GROUP } \\
\text { Group II (bupivacaine with steroid) } \\
(\mathrm{N}=60) \\
\end{array}$} \\
\hline \multirow{6}{*}{$\begin{array}{l}\text { Average pain scores } \\
(\text { Mean } \pm \text { SD })\end{array}$} & \multicolumn{2}{|c|}{$\begin{array}{l}\text { Group I (bupivacaine without steroid) } \\
\qquad(\mathrm{N}=60)\end{array}$} & \\
\hline & Baseline & $8.2 \pm 0.8$ & $8.2 \pm 1.1$ \\
\hline & 6 months & $3.6^{\star} \pm 1.1$ & $3.4^{\star} \pm 0.7$ \\
\hline & 12 months & $3.7^{\star} \pm 1.2$ & $3.4^{*} \pm 0.9$ \\
\hline & 18 months & $3.4^{\star} \pm 1.0$ & $3.5^{*} \pm 1.0$ \\
\hline & 24 months & $3.5^{\star} \pm 1.1$ & $3.2^{\star} \pm 1.0$ \\
\hline
\end{tabular}

* indicates significant difference with baseline values

$\mathrm{SD}=$ Standard deviation

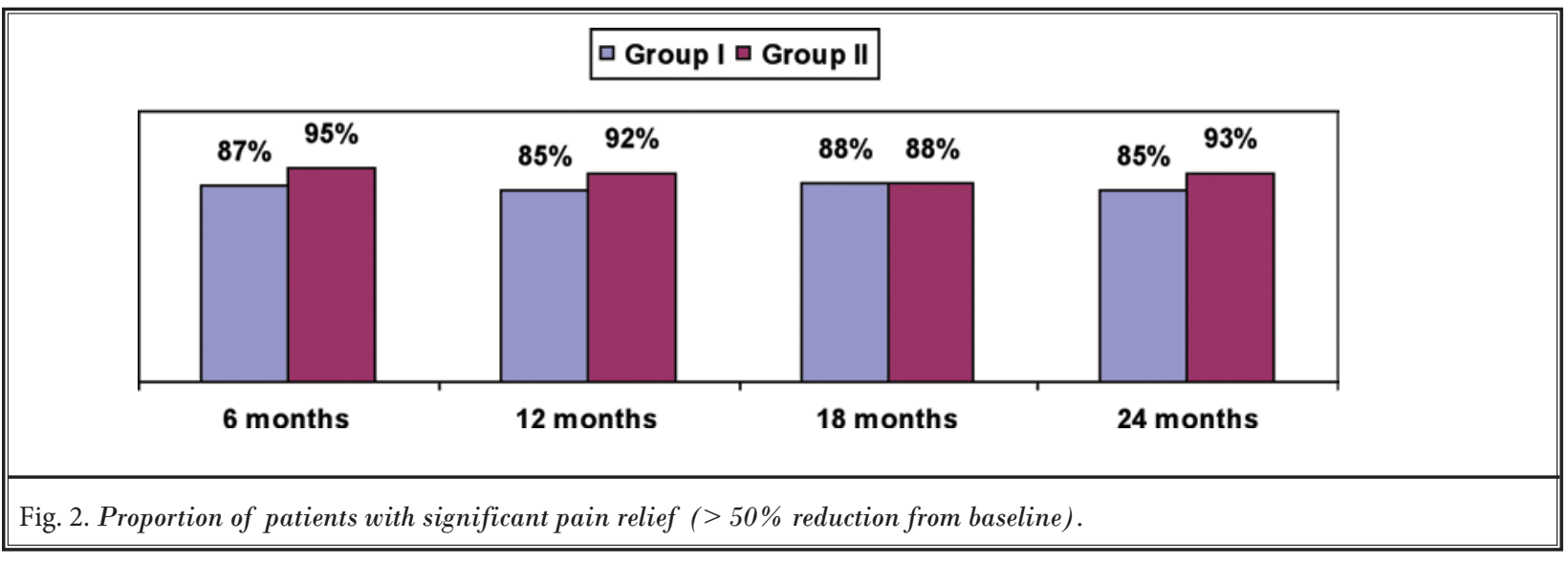

Table 3. Therapeutic procedural characteristics over a period of 2 years with average relief per procedure and total relief over a period of 2 years in weeks.

\begin{tabular}{|c|c|c|c|c|}
\hline \multirow[t]{2}{*}{$\begin{array}{c}\text { No. of } \\
\text { procedures in } \\
2 \text { years }\end{array}$} & \multicolumn{2}{|c|}{$\begin{array}{l}\text { Group I (bupivacaine without steroid) } \\
\qquad(N=60)\end{array}$} & \multicolumn{2}{|c|}{$\begin{array}{c}\text { Group II (bupivacaine with steroid) } \\
\text { (N=60) }\end{array}$} \\
\hline & Average pain relief per procedure & $\begin{array}{l}\text { Average total relief w/ sequential } \\
\text { procedures }\end{array}$ & Average pain relief per procedure & $\begin{array}{l}\text { Average total relief } w / \text { sequen- } \\
\text { tial procedures }\end{array}$ \\
\hline One & $19.5 \pm 9.2(2)$ & $19.5 \pm 9.2(2)$ & $104(1)$ & $104(1)$ \\
\hline Two & $27 \pm 24.5(4)$ & $54 \pm 49.5$ & $36 \pm 21.4(5)$ & $73 \pm 42.7$ \\
\hline Three & $24 \pm 9.8(11)$ & $72 \pm 29.3(11)$ & $26 \pm 10.2(6)$ & $78 \pm 30.5(6)$ \\
\hline Four & $15 \pm 7.3(4)$ & $61 \pm 29.3(4)$ & $17 \pm 8.3(3)$ & $68 \pm 33.1(3)$ \\
\hline Five & $20 \pm 1.1(3)$ & $99 \pm 5.5(3)$ & $17 \pm 3.4(11)$ & $86 \pm 17.1(11)$ \\
\hline Six & $14 \pm 3.2(8)$ & $86 \pm 19.1(8)$ & $15 \pm 2.8(9)$ & $88 \pm 17.1(9)$ \\
\hline Seven & $13 \pm 0.9(7)$ & $90 \pm 6.5(7)$ & $13 \pm 1.2(7)$ & $90 \pm 8.3(7)$ \\
\hline Eight & $12 \pm 1.1(18)$ & $99 \pm 8.7(18)$ & $13 \pm 0.3(17)$ & $101 \pm 2.5(17)$ \\
\hline Nine & $11 \pm 0.3(3)$ & $102 \pm 2.6(3)$ & $11(1)$ & $100(1)$ \\
\hline Average & $5.7 \pm 2.4(60)$ & $5.7 \pm 2.4(60)$ & $5.7 \pm 2.1(60)$ & $5.7 \pm 2.1(60)$ \\
\hline $\begin{array}{l}\text { Average relief } \\
\text { (per procedure) or } \\
\text { total relief in weeks }\end{array}$ & $17 \pm 9.0^{*}$ & $83 \pm 27.5^{* *}$ & $19 \pm 14.8^{\star}$ & $89 \pm 21.1^{* *}$ \\
\hline
\end{tabular}

* Average relief per procedure

${ }^{*}$ Total relief 
Average relief per procedure was $17 \pm 9.0$ and $19 \pm 14.8$ weeks per procedure, whereas it was $83 \pm 27.5$ and 89 \pm 21.1 weeks over a period of 2 years respectively for total pain relief.

\section{Functional Assessment}

Table 4 and Figure 3 illustrate functional assessment characteristics evaluated by NDI. At least 50\% improvement was seen in $63 \%$ and $68 \%$ at one year and $70 \%$ and $75 \%$, at 2 years in Groups I and II respectively.

\section{Opioid Intake}

Table 5 illustrates opioid intake with no significant change in intake of opioids.

\section{Employment Characteristics}

Table 6 illustrates the summary of employment characteristics in both groups. Among the patients eligible for employment, the total employed changed from 10 at baseline to 21 at the end of 24 months in Group I; it changed from 11 to 21 in Group II, a non-significant increase of $110 \%$ in Group I and $91 \%$ in Group II. However, the decrease in unemployment in the total sample was $22 \%$ in Group I and $20 \%$ in Group II.

\section{Adverse Events}

No major adverse events were reported during this study including infection and nerve root or spinal cord trauma.

Table 4. Functional assessment evaluated by Neck Disability Index (NDI).

\begin{tabular}{|l|l|c|c||}
\hline \hline & & $\begin{array}{c}\text { Group I } \\
\text { (bupivacaine without steroid) } \\
(\mathbf{N}=\mathbf{6 0})\end{array}$ & $\begin{array}{c}\text { Group II } \\
\text { (bupivacaine with steroid) } \\
(\mathbf{N}=\mathbf{6 0})\end{array}$ \\
\hline \multirow{4}{*}{$\begin{array}{l}\text { Neck Disability } \\
\text { Scores } \\
(\text { Mean } \pm \text { SD) }\end{array}$} & Baseline & $25.4 \pm 5.7$ & $25.1 \pm 5.0$ \\
\cline { 2 - 4 } & 6 months & $12.0^{*} \pm 5.6$ & $11.6^{*} \pm 4.2$ \\
\cline { 2 - 4 } & 12 months & $11.7^{*} \pm 5.0$ & $11.7^{*} \pm 4.6$ \\
\cline { 2 - 4 } & 18 months & $11.6^{*} \pm 5.2$ & $11.6^{*} \pm 5.2$ \\
\cline { 2 - 4 } & 24 months & $11.6^{*} \pm 4.4$ & $11.0^{*} \pm 4.7$ \\
\hline
\end{tabular}

* indicates significant difference with baseline values

$\mathrm{SD}=$ Standard deviation

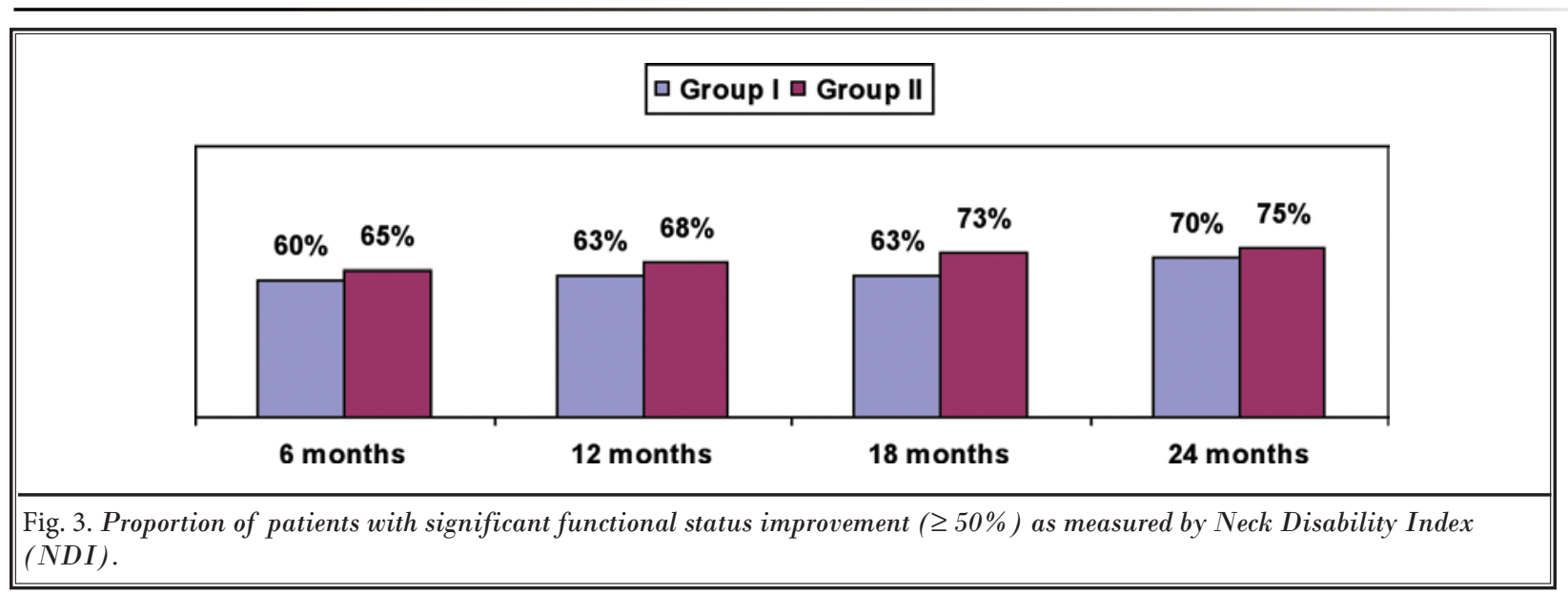

Table 5. Daily opioid intake based on morphine equivalents in milligrams.

\begin{tabular}{|l|c|c|c|}
\hline \multicolumn{1}{|c|}{ Opioid intake } & Group I & Group II & $P$ value \\
\hline Baseline & $45+43.3$ & $44+48.2$ & 0.852 \\
\hline 12 months & $35+35.3$ & $37+34.2$ & 0.775 \\
\hline 24 months & $39+43.1$ & $35+38.1$ & 0.619 \\
\hline
\end{tabular}


Table 6. Employment characteristics.

\begin{tabular}{|c|c|c|c|c|c|c|}
\hline \multirow[t]{2}{*}{ Employment Status } & \multicolumn{3}{|c|}{$\begin{array}{c}\text { Group I } \\
\text { (bupivacaine without steroid) } \\
(\mathrm{N}=60)\end{array}$} & \multicolumn{3}{|c|}{$\begin{array}{c}\text { Group II } \\
\text { (bupivacaine with steroid) } \\
(\mathbf{N}=60)\end{array}$} \\
\hline & Baseline & $\begin{array}{c}12 \\
\text { months }\end{array}$ & $\begin{array}{c}24 \\
\text { months }\end{array}$ & Baseline & $\begin{array}{c}12 \\
\text { months }\end{array}$ & $\begin{array}{c}24 \\
\text { months }\end{array}$ \\
\hline Employed part-time & 3 & 7 & 8 & 2 & 1 & 2 \\
\hline Employed full-time & 7 & 15 & 13 & 9 & 17 & 19 \\
\hline Unemployed due to pain & 5 & 0 & 1 & 5 & 3 & 1 \\
\hline Unemployed - student & 2 & 0 & 0 & 1 & 0 & 0 \\
\hline Total Unemployed & 7 & 0 & 1 & 6 & 3 & 1 \\
\hline Total Employed & 10 & 22 & 21 & 11 & 18 & 21 \\
\hline Total Employable & 17 & 22 & 22 & 17 & 21 & 22 \\
\hline Housewife & 6 & 3 & 3 & 6 & 3 & 3 \\
\hline Disabled & 31 & 29 & 29 & 31 & 29 & 28 \\
\hline Over 65 year of age & 6 & 6 & 6 & 6 & 7 & 7 \\
\hline Total Not Working & 50 & 38 & 39 & 49 & 42 & 39 \\
\hline Total & 60 & 60 & 60 & 60 & 60 & 60 \\
\hline
\end{tabular}

\section{Discussion}

The outcome results of this randomized, doubleblind controlled trial of therapeutic cervical medial branch nerve blocks in patients with function-limiting chronic neck pain, showed significant improvement with decreased pain and improvement in functional status at completion of the 2-year follow-up in $85 \%$ of patients treated with local anesthetic only and $93 \%$ of the patients with local anesthetics and steroids. Over a period of 2 years, the average pain relief per procedure ranged from 17 to 19 weeks, with an average number of procedures of 5.7 with total relief of $83 \pm$ 27.5 weeks in Group I and $89 \pm 21.1$ weeks in Group II. Opioid intake and employment status showed clinically important improvement, though it was not statistically significant. Overall, the outcome results of the current evaluation of the 2-year follow-up in managing patients with chronic neck pain with therapeutic facet joint nerve blocks was similar to preliminary and final results of the one-year follow-up $(45,62)$, and superior to a previous observational study (61). The results are similar to lumbar and thoracic facet joint nerve blocks (76-78). There are no other studies available, either observational or randomized, evaluating the therapeutic outcomes of cervical medial branch blocks with a longterm follow-up of at least 2 years.

This randomized trial was designed to reflect everyday clinical practice. We found that the 2 drugs used in combination with a local anesthetic, namely Sarapin, and steroid did not differ significantly in their response. The small differences between the 2 treatments are unlikely to be of clinical importance even in larger studies. This is one of the largest studies with the longest follow-up of an interventional technique, specifically for facet joint nerve blocks, in managing chronic neck pain. This study resolves the issue of the addition of Sarapin and steroid to local anesthetic to therapeutic cervical medial branch blocks. In the past, conflicting results have been demonstrated with regards to the effectiveness of Sarapin and steroids $(79,80)$.

The lack of additional effectiveness with the addition of a steroid beyond the effect provided by local anesthetic blocks with bupivacaine for cervical medial branch blocks provides information that there is no significant role for steroids in cervical medial branch blocks. The basis for intraarticular injections has been that there is inflammation and steroids are used to treat the inflammation. The literature is replete with descriptions of epidural corticosteroids providing a certain level of efficacy by their anti-inflammatory, immuno-suppressive, anti-edema effects and inhibition of neurotransmission within the C-fibers (81-84). Similarly, local anesthetics also have been described to provide long-term symptomatic relief, even though the mechanism of this relief remains an enigma. It has been 
postulated that local anesthetics provide relief by suppression of nociceptive discharge (85), the block of the axonal transport $(86,87)$, the block of the sympathetic reflex arc, the block of sensitization $(88,89)$, and antiinflammatory effects (90). The long-term effectiveness of local anesthetics has been shown in a host of previous studies following local anesthetic nerve blocks or epidural injections (76-78,85-96).

The limitations of this study include a lack of placebo control. As it is well known, placebo control in any neural blockade is an extremely difficult task. Further, it also adds ethical issues and difficulty with recruitment in the United States. However, multiple investigations performed in interventional pain management with descriptions of placebo control have been met with design flaws $(41,42,66,67,97,98)$. The effect of any solution injected into a closed space such as an intraarticular space or epidural space or over a nerve has not been appropriately evaluated. Carrette et al $(99,100)$, in widely acclaimed studies, showed that patients responded similarly to an intraarticular injection or epidural injection whether it contained a sodium chloride solution or local anesthetic with steroid; however, the response was low in both groups. Thus, their study (99) shows that sodium chloride solution injected into an intraauricular space has similar effects as local anesthetic with steroid; the conclusion is that intraarticular steroids are not an effective therapy. The issue is also exemplified by Birkenmaier et al (101), utilizing either pericapsular injections or medial branch blocks, who went on to perform cryoneurolysis. Not surprisingly, the results were superior in patients who were diagnosed using medial branch blocks rather than pericapsular injections of local anesthetic. This study was the basis for Chou and Huffman (97) to discard the value of diagnostic lumbar facet joint nerve blocks. In addition, the literature shows differing effects with injections of various solutions such as local anesthetic, normal saline, or dextrose and also shows differing effects by injection into the disc, facet joint, or multifidus muscle (47-50,102-104). It has been shown that a small volume of local anesthetic or normal saline abolishes muscle twitch induced by a low current $(0.5 \mathrm{~mA})$ during electrode location $(47,48,102)$. Further, there is direct evidence for spinal cord involvement in placebo analgesia (103). It also has been shown that epidurally administered sodium chloride solution provides significant improvement in the pain and function (105-107).

The evidence cited above leads to the conclusion that the effect of local anesthetic on cervical facet joint nerve blocks cannot be attributed to placebo effect, even though some have mistakenly misinterpreted this to be the case for facet joint nerve blocks $(46,108)$. Placebo effects are not expected to be seen in a high proportion of patients, nor are they expected to be long lasting with repeat interventions over a period of 2 years. However, the limitations of the lack of placebo must not be underestimated. If feasible, a placebocontrolled study with appropriate design that includes not injecting the placebo solution over the facet joint nerves, and subsequent results, would be highly valid and provide conclusive knowledge on the issue of placebo-controlled blocks.

The second issue is related to the reliability of the controlled, comparative local anesthetic blocks which have been criticized and their validity as precision diagnostic techniques has been questioned and debated $(37-42,109)$. The issues related to the accuracy of diagnostic facet joint nerve blocks include the reference standard, prior exposure to opioids, sedation, systemic local anesthetic effect, and non-specific effect resulting in positive results $(23,26-28,30,53-57)$. The validity of controlled facet joint nerve blocks as a gold standard or reference standard in the diagnosis of lumbar facet joint pain has been established (51). Reference standard is established in surgical situations via biopsy or autopsy. However, these are difficult to apply in the diagnosis of chronic spinal pain of facet joint origin. Thus, the long-term or dedicated clinical follow-up of the subjects appears to be the only solution in establishing a reference standard with controlled facet joint nerve blocks (110). Based on the criterion standard of long-term follow-up, controlled diagnostic lumbar facet joint nerve blocks have been shown to be valid utilizing the criteria of $80 \%$ pain relief and the ability to perform previously painful movements, with a sustained diagnosis of lumbar facet joint pain in at least $89.5 \%$ of the patients at the end of 2-year follow-up (51). However, the diagnosis was sustained in only $51 \%$ of the patients with $50 \%$ relief at the end of 2 years (51). Thus, the controlled diagnostic blocks utilized in this study appear to be reliable.

These outcome results are from a real world setting describing patients in a private practice setting in the United States at an interventional pain management practice, with the results generalizable to similar settings; however, the results are not applicable in the general population unless the same methodology is utilized with diagnosis and therapy. Further, generaliz- 
ability of the findings of this study may only be feasible with publication of studies utilizing larger populations in multiple settings.

\section{Conclusions}

The evidence in this report demonstrates cervical facet joint pain diagnosed by controlled, comparative local anesthetic blocks with a criteria of $80 \%$ pain relief, which is sustained after prior painful movements for an appropriate duration of action of local anesthetic, may be treated with cervical medial branch blocks with or without steroid. Therapeutic cervical medial branch blocks provided approximately 17 to 19 weeks of relief requiring approximately 6 episodes of treatments over a period of 2 years, with $85 \%, 92 \%$, and $85 \%, 93 \%$ significant improvement at one and 2 years in Groups I and II respectively.

\section{Acknowledgments}

The authors wish to thank Sekar Edem for assistance in the search of the literature, Tom Prigge for manuscript review, and Tonie M. Hatton and Diane E. Neihoff, transcriptionists, for their assistance in preparation of this manuscript. We would like to thank the editorial board of Pain Physician for review and criticism in improving the manuscript.

\section{References}

1. Martin BI, Deyo RA, Mirza SK, Turner JA, Comstock BA, Hollingworth W, Sullivan SD. Expenditures and health status among adults with back and neck problems. JAMA 2008; 299:656-664. Erratum in: JAMA 2008, 299:2630.

2. Thelin A, Holmberg S, Thelin N. Functioning in neck and low back pain from a 12-year perspective: A prospective population-based study. J Rehabil Med 2008; 40:555-561.

3. Côté P, Cassidy JD, Carroll LJ, Kristman $V$. The annual incidence and course of neck pain in the general population: $A$ population-based cohort study. Pain 2004; 112:267-273.

4. Carroll LJ, Hogg-Johnson S, van der Velde G, Haldeman S, Holm LW, Carragee EJ, Hurwitz EL, Côté P, Nordin M, Peloso PM, Guzman J, Cassidy JD; Bone and Joint Decade 2000-2010 Task Force on Neck Pain and Its Associated Disorders. Course and prognostic factors for neck pain in the general population: Results of the Bone and Joint Decade 2000-2010 Task Force on Neck Pain and Its Associated Disorders. Spine (Phila Pa 1976) 2008; 33 (4 Suppl):S75-S82.

5. Borghouts JA, Koes BW, Bouter LM. The clinical course and prognostic factors of non-specific neck pain: A systematic review. Pain 1998; 77:1-13.

6. Holmberg SA, Thelin AG. Primary care consultation, hospital admission, sick leave and disability pension owing to neck and low back pain: a 12-year prospective cohort study in a rural population. BMC Musculoskelet Disord 2006; 7:66.

7. Martin BI, Turner JA, Mirza SK, Lee MJ, Comstock BA, Deyo RA. Trends in health care expenditures, utilization, and health status among US adults with spine problems, 1997-2006. Spine (Phila Pa 1976) 2009; 34:2077-2084.

8. Manchikanti L. Singh V, Datta S, Cohen SP, Hirsch JA. Comprehensive review of epidemiology, scope, and impact of spinal pain. Pain Physician 2009; 12:E35E70.

9. Côté P, Cassidy JD, Carroll L. The Saskatchewan Health and Back Pain Survey. The prevalence of neck pain and related disability in Saskatchewan adults. Spine (Phila Pa 1976) 1998; 23:16891698.

10. Hogg-Johnson S, van der Velde G, Carroll LJ, Holm LW, Cassidy JD, Guzman J, Côté P, Haldeman S, Ammendolia C, Carragee E, Hurwitz E, Nordin M, Peloso P; Bone and Joint Decade 2000-2010 Task Force on Neck Pain and Its Associated Disorders. The burden and determinants of neck pain in the general population: Results of the Bone and Joint Decade 2000-2010 Task Force on Neck Pain and its associated disorders. Spine (Phila Pa 1976) 2008; 33:S39-S51.

11. Fejer R, Kyvik KO, Hartvigsen J. The prevalence of neck pain in the world population: a systematic critical review of the literature. Eur Spine J 2006; 15:834848.

12. Huisstede BM, Wijnhoven HA, BiermaZeinstra SM, Koes BW, Verhaar JA, Picavet $S$. Prevalence and characteristics of complaints of the arm, neck, and/or shoulder (CANS) in the open population. Clin J Pain 2008; 24:253-259.

13. Hartvigsen J, Christensen K, Frederiksen $\mathrm{H}$. Back and neck pain exhibit many common features in old age: a population-based study of 4,486 Danish twins $70-102$ years of age. Spine (Phila Pa
1976) 2004; 29:576-580.

14. Hartvigsen J, Frederiksen $\mathrm{H}$, Christensen K. Back and neck pain in seniors - prevalence and impact. Eur Spine J 2006; 15:802-806.

15. Hartvigsen J, Christensen K. Pain in the back and neck are with us until the end: a nationwide interview-based survey of Danish 100-year-olds. Spine $(P h$ ila Pa 1976) 2008; 33:909-913.

16. Holm LW, Carroll LJ, Cassidy JD, HoggJohnson S, Côté P, Guzman J, Peloso P, Nordin M, Hurwitz E, van der Velde G, Carragee E, Haldeman S; Bone and Joint Decade 2000-2010 Task Force on Neck Pain and Its Associated Disorders. The burden and determinants of neck pain in whiplash-associated disorders after traffic collisions: Results of the Bone and Joint Decade 2000-2010 Task Force on Neck Pain and its Associated Disorders. Spine (Phila Pa 1976) 2008; 33:S52-S59.

17. Côté P, Kristman V, Vidmar M, Van Eerd D, Hogg-Johnson S, Beaton D, Smith PM: The prevalence and incidence of work absenteeism involving neck pain: a cohort of Ontario lost-time claimants. Spine (Phila Pa 1976) 2008; 33:S192S198.

18. Côté P, van der Velde G, Cassidy JD, Carroll LJ, Hogg-Johnson S, Holm LW, Carragee EJ, Haldeman S, Nordin M, Hurwitz EL, Guzman J, Peloso PM; Bone and Joint Decade 2000-2010 Task Force on Neck Pain and Its Associated Disorders. The burden and determinants of neck pain in workers. Results of the Bone and Joint Decade 2000-2010 Task Force on Neck Pain and Its Associated Disorders. Spine (Phila Pa 1976) 2008; 33:S60-S74. 
19. Manchikanti L, Singh V, Pampati V, Smith HS, Hirsch JA. Analysis of growth of interventional techniques in managing chronic pain in the medicare population: A 10-year evaluation from 1997 to 2006. Pain Physician 2009; 12:9-34.

20. Saskatchewan Workers' Compensation Board. Statistical Supplement 2005. www.wcbsask.com/WCBPortal/ShowProperty/WCBRepository/formsPublications/publications/annualPubs/ 2005StatisticalSummary//pdfContent.

21. Manchikanti L, Pampati V, Boswell MV, Smith HS, Hirsch JA. Analysis of the growth of epidural injections and costs in the Medicare population: A comparative evaluation of 1997, 2002, and 2006 data. Pain Physician 2010; 13:199-212.

22. Manchikanti L, Pampati V, Singh V, Boswell MV, Smith HS, Hirsch JA. Explosive growth of facet joint interventions in the Medicare population in the United States: A comparative evaluation of 1997, 2002, and 2006 data. BMC Health Serv Res 2010; 10:84.

23. Falco FJE, Erhart S, Wargo BW, Bryce DA, Atluri S, Datta S, Hayek SM. Systematic review of diagnostic utility and therapeutic effectiveness of cervical facet joint interventions. Pain Physician 2009; 12:323-344.

24. Sehgal N, Dunbar EE, Shah RV, Colson JD. Systematic review of diagnostic utility of facet (zygapophysial) joint injections in chronic spinal pain: an update. Pain Physician 2007; 10:213-228.

25. Yin W, Bogduk N. The nature of neck pain in a private pain clinic in the United States. Pain Med 2008; 9:196-203.

26. Barnsley L, Lord SM, Wallis BJ, Bogduk N. The prevalence of chronic cervical zygapophyseal joint pain after whiplash. Spine (Phila Pa 1976) 1995; 20:20-26.

27. Barnsley L, Lord S, Wallis B, Bogduk $N$. False-positive rates of cervical zygapophysial joint blocks. Clin J Pain 1993; 9:124-130.

28. Lord SM, Barnsley L, Wallis BJ, Bogduk N. Chronic cervical zygapophysial joint pain with whiplash: a placebo-controlled prevalence study. Spine (Phila Pa 1976) 1996; 21:1737-1745.

29. Speldewinde G, Bashford G, Davidson I. Diagnostic cervical zygapophyseal joint blocks for chronic cervical pain. Med J Aust 2001; 174:174-176.

30. Manchikanti L, Boswell MV, Singh V, Pampati V, Damron KS, Beyer CD. Prevalence of facet joint pain in chronic spinal pain of cervical, thoracic, and lum- bar regions. BMC Musculoskelet Disord 2004; 5:15.

31. Manchukonda R, Manchikanti KN, Cash KA, Pampati V, Manchikanti L. Facet joint pain in chronic spinal pain: an evaluation of prevalence and false-positive rate of diagnostic blocks. / Spinal Disord Tech 2007; 20:539-545.

32. Manchikanti L, Manchikanti K, Pampati V, Brandon D, Giordano J. The prevalence of facet joint-related chronic neck pain in postsurgical and non-postsurgical patients: a comparative evaluation. Pain Pract 2008; 8:5-10.

33. Rubinstein SM, van Tulder M. A best-evidence review of diagnostic procedures for neck and low-back pain. Best Pract Res Clin Rheumatol 2008; 22:471-482.

34. Manchikanti L, Boswell MV, Singh V, Benyamin RM, Fellows B, Abdi S, Buenaventura RM, Conn A, Datta S, Derby R, Falco FJE, Erhart S, Diwan S, Hayek SM, Helm S, Parr AT, Schultz DM, Smith HS, Wolfer LR, Hirsch JA. Comprehensive evidence-based guidelines for interventional techniques in the management of chronic spinal pain. Pain Physician 2009; 12:699-802.

35. Manchikanti L, Boswell MV, Singh V, Derby R, Fellows B, Falco FJE, Datta S, Smith HS, Hirsch JA. Comprehensive review of neurophysiologic basis and diagnostic interventions in manag. ing chronic spinal pain. Pain Physician 2009; 12:E71-E120.

36. Manchikanti L, Boswell MV, Datta S, Fellows B, Abdi S, Singh V, Benyamin RM, Falco FJE, Helm S, Hayek S, Smith HS. Comprehensive review of therapeutic interventions in managing chronic spinal pain. Pain Physician 2009; 12:E123E198.

37. King W, Lau P, Lees R, Bogduk N. The validity of manual examination in assessing patients with neck pain. Spine J 2007; 7:22-26.

38. Carragee EJ, Haldeman S, Hurwtiz E. The pyrite standard: The Midas touch in the diagnosis of axial pain syndromes. Spine J 2007; 7:27-31.

39. Bogduk N. In defense of King et al: The validity of manual examination in assessing patients with neck pain. Spine J 2007; 7:749-752.

40. Carragee EJ, Haldeman S, Hurwtiz E. Response to Bogduk. Letter to the Editor. Spine J 2007; 7:752-753.

41. Manchikanti L, Datta S, Derby R, Wolfer LR, Benyamin RM, Hirsch JA. A critical review of the American Pain Society clinical practice guidelines for interven- tional techniques: Part 1. Diagnostic interventions. Pain Physician 2010; 13: E141-E174.

42. Manchikanti L, Datta S, Gupta S, Munglani R, Bryce DA, Ward SP, Benyamin RM, Sharma ML, Helm II S, Fellows B, Hirsch JA. A critical review of the American Pain Society clinical practice guidelines for interventional techniques: Part 2. Therapeutic interventions. Pain Physician 2010; 13:E215-E264.

43. Manchikanti L, Shah RV, Datta S, Singh V. Critical evaluation of interventional pain management literature provides inaccurate conclusions. Spine / 2009; 9:706-708.

44. Smuck M, Levin JH: RE: Manchikanti L, Singh V, Falco FJE, Cash KA, Fellows B. Cervical medial branch blocks for chronic cervical facet joint pain: A randomized double-blind, controlled trial with one-year follow-up. Spine (Phila Pa 1976) 2008; 33:1813-20. Spine (Phila Pa 1976) 2009; 34:1116.

45. Manchikanti L, Singh V, Falco FJE. In response to Smuck M, Levin JH. RE: Manchikanti L, Singh V, Falco FJE, Cash KA, Fellows B. Cervical medial branch blocks for chronic cervical facet joint pain: A randomized double-blind, controlled trial with one-year follow-up. Spine (Phila Pa 1976) 2009; 34:11161117.

46. Levin JH. Prospective, double-blind, randomized placebo-controlled trials in interventional spine: What the highest quality literature tells us. Spine J 2009; 9:690-703.

47. Pham Dang C, Lelong A, Guilley J, Nguyen JM, Volteau C, Venet G, Perrier C, Lejus C, Blanloeil Y. Effect on neurostimulation of injectates used for perineural space expansion before placement of a stimulating catheter: Normal saline versus dextrose $5 \%$ in water. Reg Anesth Pain Med 2009; 34:398-403.

48. Tsui BC, Kropelin B, Ganapathy S, Finucane B. Dextrose $5 \%$ in water: Fluid medium maintaining electrical stimulation of peripheral nerve during stimulating catheter placement. Acta Anaesthesiol Scand 2005; 49:1562-1565.

49. Indahl A, Kaigle AM, Reikeräs O, Holm $\mathrm{SH}$. Interaction between the porcine lumbar intervertebral disc, zygapophysial joints, and paraspinal muscles. Spine (Phila Pa 1976) 1997; 22:28342840.

50. Indahl A, Kaigle A, Reikeräs O, Holm S. Electromyographic response of the porcine multifidus musculature after nerve stimulation. Spine (Phila $\mathrm{Pa}$ 
1976) 1995; 20:2652-2658.

51. Pampati S, Cash KA, Manchikanti L. Accuracy of diagnostic lumbar facet joint nerve blocks: A 2-year follow-up of 152 patients diagnosed with controlled diagnostic blocks. Pain Physician 2009; 12:855-866.

52. Manchikanti L, Pampati S, Cash KA. Making sense of accuracy of diagnostic lumbar facet joint nerve blocks: An assessment of implications of $50 \%$ relief, $80 \%$ relief, single block or controlled diagnostic blocks. Pain Physician 2010; 13:133-143.

53. Manchikanti L, Manchikanti K, Cash KA, Singh V, Giordano J. Age-related prevalence of facet joint involvement in chronic neck and low back pain. Pain Physician 2008; 11:67-75.

54. Manchikanti L, Cash KA, Pampati V, Fellows B. Influence of psychological variables on the diagnosis of facet joint involvement in chronic spinal pain. Pain Physician 2008; 11:145-160.

55. Manchikanti L, Boswell MV, Manchukonda R, Cash KA, Giordano. Influence of prior opioid exposure on diagnostic facet joint nerve blocks. J Opioid Manage 2008; 4:351-360.

56. Manchikanti L, Pampati V, Damron KS, MCManus CD, Jackson SD, Barnhill RC, Martin JC. A randomized, prospective, double-blind, placebo-controlled evaluation of the effect of sedation on diagnostic validity of cervical facet joint pain. Pain Physician 2004; 7:301-309.

57. Manchikanti L, Pampati V, Damron KS, McManus CD, Jackson SD, Barnhill RC, Martin JC. The effect of sedation on diagnostic validity of facet joint nerve blocks: An evaluation to assess similarities in population with involvement in cervical and lumbar regions (ISRCTNo: 76376497). Pain Physician 2006; 9:4752.

58. Manchikanti L, Pampati V, Damron KS. The role of placebo and nocebo effects of perioperative administration of sedatives and opioids in interventional pain management. Pain Physician 2005; 8:349-355.

59. American Society of Anesthesiologists Task Force on Chronic Pain Management; American Society of Regional Anesthesia and Pain Medicine. Practice guidelines for chronic pain management: an updated report by the American Society of Anesthesiologists Task Force on Chronic Pain Management and the American Society of Regional Anesthesia and Pain Medicine. Anes- thesiology 2010; 112:810-833.

6o. Manchikanti L, Singh V, Derby R, Schultz DM, Benyamin RM, Prager JP, Hirsch JA. Reassessment of evidence synthesis of occupational medicine practice guidelines for interventional pain management. Pain Physician 2008; 11:393482.

61. Manchikanti L, Manchikanti KN, Damron KS, Pampati V. Effectiveness of cervical medial branch blocks in chronic neck pain: A prospective outcome study. Pain Physician 2004; 7:195-202.

62. Manchikanti L, Damron KS, Cash KA, Manchukonda R, Pampati V. Therapeutic cervical medial branch blocks in managing chronic neck pain: a preliminary report of a randomized, double-blind, controlled trial: Clinical Trial NCTo033272. Pain Physician 2006; 9:333-346.

63. Merskey H, Bogduk N. Cervical zygapophysial joint pain. In: Classification of Chronic Pain. Descriptions of Chronic Pain Syndromes and Definition of Pain Terms. 2nd ed. Task Force on Taxonomy of the International Association for the Study of Pain. IASP Press, Seattle, 1994, pp108-109.

64. Altman DG, Schulz KF, Moher D, Egger M, Davidoff F, Elbourne D, Gøtzsche PC, Lang T; CONSORT GROUP (Consolidated Standards of Reporting Trials). The revised CONSORT statement for reporting randomized trials: explanation and elaboration. Ann Intern Med 2001; 134:663-694.

65. Moher D, Schulz KF, Altman D, for the CONSORT Group. The CONSORT statement: revised recommendations for improving the quality of reports of parallel-group randomized trials. JAMA 2001; 285:1987-1991.

66. Manchikanti L, Hirsch JA, Smith HS. Evidence-based medicine, systematic reviews, and guidelines in interventional pain management: Part 2: randomized controlled trials. Pain Physician 2008; 11:717-773.

67. Manchikanti L, Benyamin RM, Helm S, Hirsch JA. Evidence-based medicine, systematic reviews, and guidelines in interventional pain management: Part 3: Systematic reviews and meta-analysis of randomized trials. Pain Physician 2009; 12:35-72.

68. Jensen MP, Karoly P. Self-report scales and procedures for assessing pain in adults. In Turk DC, Melzack R (eds). Handbook of Pain Assessment, 2nd Edition. Guilford Press, New York, 2001, pp 15-34.

69. Cleland JA, Childs JD, Whitman JM. Psychometric properties of the Neck Disability Index and Numeric Pain Rating Scale in patients with mechanical neck pain. Arch Phys Med Rehabil 2008; 89:69-74.

70. Carragee EJ. The rise and fall of the "minimum clinically important difference." Spine J 2010; 10:283-284.

71. Carragee EJ, Chen I. Minimum acceptable outcomes after lumbar spinal fusion. Spine J 2010; 10:313-320.

72. Pereira J, Lawlor P, Vigano A, Dorgan M, Bruera E. Equianalgesic dose ratios for opioids. A critical review and proposals for long-term dosing. J Pain Symptom Manage 2001; 22:672-687. (Narcotic analgesic converter, GlobalRPh Inc. www.globalrph.com/narcotic.cgi)

73. Lord SM, Barnsley L, Wallis BJ, McDonald GJ, Bogduk N. Percutaneous radiofrequency neurotomy for chronic cervical zygapophysial joint pain. N Engl J Med 1996; 335:1721-1726.

74. van Kleef M, Barendse GA, Kessels A, Weber WE, van Kleef M. Randomized trial of radiofrequency lumbar facet denervation for chronic low back pain. Spine (Phila Pa 1976) 1999; 24:19371942.

75. Koes BW, Scholten RJ, Mens JM, Bouter LM. Efficacy of epidural steroid injections for low-back pain and sciatica: a systematic review of randomized clinical trials. Pain 1995; 63:279-288.

76. Manchikanti L, Singh V, Falco FJ, Cash KA, Pampati V. Lumbar facet joint nerve blocks in managing chronic facet joint pain: One-year follow-up of a randomized, double-blind controlled trial: Clinical Trial NCTo0355914. Pain Physician 2008; 11:121-132.

77. Manchikanti L, Singh V, Falco FJE, Cash KA, Pampati V. Effectiveness of thoracic medial branch blocks in managing chronic pain: a preliminary report of a randomized, double-blind controlled trial; Clinical trial NCTo0355706. Pain Physician 2008; 11:491-504.

78. Manchikanti L, Singh V, Falco FJE, Cash KA, Pampati V. Evaluation of lumbar facet joint nerve blocks in managing chronic low back pain: A randomized, double-blind, controlled trial with a 2-year follow-up. Int J Med Sci 2010; 7:124-135.

79. Manchikanti L, Pampati V, Fellows B, Bakhit CE. The diagnostic validity and therapeutic value of lumbar facet joint nerve blocks with or without adjuvant 
agents. Curr Rev Pain 2000; 4:337344 .

80. Manchikanti KN, Pampati V, Damron KS, McManus CD. A double-blind, controlled evaluation of the value of Sarapin in neural blockade. Pain Physician 2004; 7:59-62.

81. Hayashi N, Weinstein JN, Meller ST, Lee HM, Spratt KF, Gebhart GF. The effect of epidural injection of betamethasone or bupivacaine in a rat model of lumbar radiculopathy. Spine (Phila Pa 1976) 1998; 23:877-885.

82. Lee HM, Weinstein JN, Meller ST, Hayashi N, Spratt KF, Gebhart GF. The role of steroids and their effects on phospholipase A2. An animal model of radiculopathy. Spine (Phila Pa 1976) 1998; 23:1191-1196.

83. Johansson A, Hao J, Sjolund B. Local corticosteroid application blocks transmission in normal nociceptive C-fibres. Acta Anaesthesiol Scand 1990; 34:335338.

84. Pasqualucci A, Varrassi $G$, Braschi A, Peduto VA, Brunelli A, Marinangeli $F$, Gori F, Colò F, Paladini A, Mojoli F. Epidural local anesthetic plus corticosteroid for the treatment of cervical brachial radicular pain: Single injection versus continuous infusion. Clin J Pain 2007; 23:551-57.

85. Arner S, Lindblom U, Meyerson BA, Molander C. Prolonged relief of neuralgia after regional anesthetic block. A call for further experimental and systematic clinical studies. Pain 1990; 43:287297.

86. Lavoie PA, Khazen T, Filion PR: Mechanisms of the inhibition of fast axonal transport by local anesthetics. Neuropharmacology 1989; 28:175-181.

87. Bisby MA. Inhibition of axonal transport in nerves chronically treated with local anesthetics. Exp Neurol 1975; 47:481-489.

88. Katz WA, Rothenberg R. The nature of pain: Pathophysiology. I Clin Rheumatol 2005; 11(2 Suppl):S11-15.

89. Melzack R, Coderre TJ, Katz J, Vaccarino AL. Central neuroplasticity and pathological pain. Ann N Y Acad Sci 2001; 933:157-174.

90. Cassuto J, Sinclair R, Bonderovic M. Anti-inflammatory properties of local anesthetics and their present and potential clinical implications. Acta An aesthesiol Scand 2006; 50:265-282.

91. Wertheim HM, Rovenstine EA. Suprascapular nerve block. Anesthesiology 1941; 2:541-545.
92. Riew KD, Park JB, Cho YS, Gilula L, Patel A, Lenke LG, Bridwell KH. Nerve root blocks in the treatment of lumbar radicular pain. A minimum five-year follow-up. J Bone Joint Surg Am 2006; 88:1722-1725.

93. Manchikanti L, Cash KA, McManus CD, Pampati V, Smith HS. Preliminary results of randomized, equivalence trial of fluoroscopic caudal epidural injections in managing chronic low back pain: Part 1. Discogenic pain without disc herniation or radiculitis. Pain Physician 2008; 11:785-800.

94. Manchikanti L, Singh V, Cash KA, Pampati V, Damron KS, Boswell MV. Preliminary results of randomized, equivalence trial of fluoroscopic caudal epidural injections in managing chronic low back pain: Part 2. Disc herniation and radiculitis. Pain Physician 2008; 11:801-815.

95. Manchikanti L, Singh V, Cash KA, Pampati V, Datta S. Preliminary results of randomized, equivalence trial of fluoroscopic caudal epidural injections in managing chronic low back pain: Part 3. Post surgery syndrome. Pain Physician 2008; 11:817-831.

96. Manchikanti L, Cash KA, McManus CD, Pampati V, Abdi S. Preliminary results of randomized, equivalence trial of fluoroscopic caudal epidural injections in managing chronic low back pain: Part 4. Spinal stenosis. Pain Physician 2008; 11:833-848.

97. Chou R, Huffman L. Evaluation and Management of Low Back Pain: Evidence Review. American Pain Society; Glenview, IL, 2009.

http://www.ampainsoc.org/pub/pdf/LBPEvidRev.pdf

98. Chou R, Atlas SJ, Stanos SP, Rosenquist RW: Nonsurgical interventional therapies for low back pain: A review of the evidence for an American Pain Society clinical practice guideline. Spine (Phila Pa 1976) 2009; 34:1078-1093.

99. Carette S, Marcoux S, Truchon R, Grondin C, Gagnon J, Allard Y, Latulippe M. A controlled trial of corticosteroid injections into facet joints for chronic low back pain. N Engl J Med 1991; 325:1002-1007.

100. Carette S, Leclaire R, Marcoux S, Morin F, Blaise GA, St-Pierre A, Truchon R, Parent $F$, Levesque J, Bergeron V, Montminy $P$, Blanchette C. Epidural corticosteroid injections for sciatica due to herniated nucleus pulposus. $N$ Engl I Med 1997; 336:1634-1640.
101. Birkenmaier C, Veihelmann A, Trouillier HH, Hausdorf J, von Schulze Pellengahr C. Medial branch blocks versus pericapsular blocks in selecting patients for percutaneous cryodenervation of lumbar facet joints. Reg Anesth Pain Med 2007; 32:27-33.

102. Johnson CR, Barr RC, Klein SM. A computer model of electrical stimulation of peripheral nerves in regional anesthesia. Anesthesiology 2007; 106:323-30.

103. Eippert F, Finsterbusch J, Bingel U, Büchel C. Direct evidence for spinal cord involvement in placebo analgesia. Science 2009; 326:404.

104. Tsui BC, Kropelin B, Ganapathy S, Finucane B. Dextrose $5 \%$ in water: Fluid medium maintaining electrical stimulation of peripheral nerve during stimulating catheter placement. Acta Anaesthesiol Scand 2005; 49:1562-1565.

105. Bhatia MT, Parikh LCJ. Epidural saline therapy in lumbo-sciatic syndrome. J Indian Med Assoc 1966; 47:537-542.

106. Gupta AK, Mital VK, Azmi RU. Observations of the management of lumbosciatic syndromes (sciatica) by epidural saline. J Indian Med Assoc 1970; 54:194-196.

107. Wittenberg RH, Greskötter KR, Steffen $R$, Schoenfeld BL. Is epidural injection treatment with hypertonic saline solution in intervertebral disk displacement useful? (The effect of $\mathrm{NaCl}$ solution on intervertebral disk tissue). $Z$ Orthop Ihre Grenzgeb 1990; 128:223226.

108. O’Neill C. Re: Manchikanti L, Singh V, Falco FJE, et al. Cervical medial branch blocks for chronic cervical facet joint pain. A randomized, double-blind, controlled trial with one-year follow-up. Spine 2008, 33:1813-20. Spine (Phila $\mathrm{Pa}$ 1976) 2009; 34:1117-1118.

109. Bogduk N, McGuirk B. Causes and sources of chronic low back pain. In Bogduk N, McGuirk B (eds). Medical Management of Acute and Chronic Low Back Pain. An Evidence-Based Approach: Pain Research and Clinical Management. Volume 13. Elsevier Science BV, Amsterdam, 2002, pp 115126.

110. Saal JS. General principles of diagnostic testing as related to painful lumbar spine disorders. A critical appraisal of current diagnostic techniques. Spine Phila Pa 1976) 2002; 27:2538-2545. 